\title{
A study of the diatom-dominated microplankton summer assemblages in coastal waters from Terre Adélie to the Mertz Glacier, East Antarctica $\left(1^{\circ}{ }^{\circ} \mathrm{E}-145^{\circ} \mathrm{E}\right)$
}

\author{
C. Beans $\cdot$ J. H. Hecq $\cdot$ P. Koubbi . \\ C. Vallet $\cdot$ S. Wright $\cdot$ A. Goffart
}

Received: 13 August 2007/Revised: 14 April 2008/Accepted: 15 April 2008

(C) Springer-Verlag 2008

\begin{abstract}
In January 2004 the microplankton community from the coastal waters of Terre Adélie and Georges V Land $\left(139^{\circ} \mathrm{E}-145^{\circ} \mathrm{E}\right)$ was studied. Results showed a diatomdominated bloom with chlorophyll $a$ levels averaging $0.64 \mu \mathrm{g} \mathrm{l}^{-1}$ at $5 \mathrm{~m}$ depth (range $0.21-1.57 \mu \mathrm{g} \mathrm{l}^{-1}$ ). Three geographic assemblages of diatoms were identified, based on principal diatom taxa abundances. The stratified waters near the Mertz Glacier presented highest phytoplankton biomasses $\left(0.28-1.57 \mu \mathrm{g} \mathrm{Chl} a \mathrm{l}^{-1}\right.$ at $\left.5 \mathrm{~m}\right)$ and diatom abundances $\left(6,507-70,274\right.$ cells $1^{-1}$ at $\left.5 \mathrm{~m}\right)$, but low diversity, dominated by Fragilariopsis spp. Lower biomasses (0.38-0.94 $\mu \mathrm{g} \mathrm{Chl} a \mathrm{l}^{-1}$ at $\left.5 \mathrm{~m}\right)$ and abundances (394-9,058 cells $1^{-1}$ at $5 \mathrm{~m}$ ) were observed in the mixed waters around the Astrolabe Glacier with a diverse diatom community characterised by larger species Corethron
\end{abstract}

C. Beans · J. H. Hecq · A. Goffart ( $\varangle)$

Laboratoire d'Océanologie, Mare Center, Université de Liège,

Bat. B6c, Allée de la Chimie, 3., B4000 Liège, Belgium

e-mail: Anne.Goffart@ulg.ac.be

P. Koubbi

Laboratoire d'Océanographie de Villefranche,

Université Paris VI. CNRS, BP 28, F06230 Villefranche sur mer,

France

C. Vallet

Centre IUFM Nord-Pas de Calais, Université d'Artois,

10 rue Hippolyte Adam, F62230 Outreau, France

C. Vallet

Laboratoire d'Océanologie et de Géosciences,

Université du Littoral Côte d'Opale, CNRS, UMR,

8187 LOG, 32 Avenue Foch, F62930 Wimereux, France

\section{S. Wright}

Australian Government Antarctic Division and Antarctic Climate and Ecosystems Cooperative Research Centre, Channel Highway, Kingston, TAS 7050, Australia pennatum and Rhizosolenia spp. Finally an intermediate zone between them over the shallower shelf waters of the Adélie Bank represented by Chaetoceros criophilus, where biomasses (0.21-0.35 $\mu \mathrm{g} \mathrm{Chl} a 1^{-1}$ at $\left.5 \mathrm{~m}\right)$ and abundances $\left(1,190-5,431{\text { cells } 1^{-1}}^{-1} 5 \mathrm{~m}\right)$ were lowest, coinciding with the presence of abundant herbivorous zooplankton.

Keywords East Antarctica · Terre Adélie .

Phytoplankton · Diatoms

\section{Introduction}

Studies of Antarctic plankton dating back to some of the earliest polar expeditions in the mid-1880s already mention the omnipresence and importance of phytoplankton in the water, and an interest in polar phytoplankton and its essential role in the primary production has generated much data over the past century (Knox 1994; El-Sayed 2005). Nevertheless, although the microplankton communities in Southern Ocean waters have been studied extensively, most studies have been located in waters off the Antarctic Peninsula and the Ross, Weddell, Bellingshausen and Scotia Seas (Froneman et al. 1997; El-Sayed 2005; Fonda Umani et al. 2005; Garibotti et al. 2005) and were done in relation to the general oceanic circulation. This contrasts with the rarity of studies in Eastern Antarctica (particularly in the western Pacific Ocean Sector), partly due to the frequent persistence of sea-ice along the coast in the austral summer and the low biomass of krill present in the region, lessening the economic interest of the region (Nicol et al. 2000; Harris et al. 2003).

The rarely studied shelf waters of Terre Adélie and King Georges V Land (from $139^{\circ} \mathrm{E}$ to $146^{\circ} \mathrm{E}$ ) are of interest notably due to the formation of Antarctic Deep Water in 
the Mertz Glacier region and bays (Bindoff et al. 2000) and to the presence of two coastal polynyas, biologically productive areas of open water or reduced sea-ice cover within the ice pack, near Dumont d'Urville and the Mertz Glacier (Arrigo and van Dijken 2003; Sambrotto et al. 2003). In the Mertz Glacier Polynya, which opens up before the Dumont d'Urville Polynya, the phytoplankton bloom has been observed to last 3 months, although there are usually two peaks: late December and early March (Arrigo and van Dijken 2003).

Early studies of the phytoplankton off Terre Adélie by Manguin in 1949-1950 and Franguelli in 1950-1952 (in Riaux-Gobin et al. 2003) were centred on diatom taxonomy. Since then, subsequent surveys in the region have studied the microplankton community in offshore waters north of the shelf break and close to the Polar Front (Chiba et al. 2000; Waters et al. 2000). Studies near the coast have centred on the sea-ice communities (Delille et al. 1995; Riaux-Gobin et al. 2000, 2003, 2005) or concentrated on phytoplankton biomass and primary production in the Mertz Polynya (Sambrotto et al. 2003; Vaillancourt et al. 2003).

Most of the recent oceanographic studies done in Terre Adélie (including the present one) have taken place within the framework of the French ICOTA (Ichthyologie Côtière en Terre Adélie) programme, funded by the French Polar Institute (IPEV). This has been in place since 1996, with yearly summer campaigns located over the continental platform off the coast from Dumont d'Urville Station in Terre Adélie to the Mertz Glacier in East Antarctica $\left(139^{\circ} \mathrm{E}-146^{\circ} \mathrm{E}\right)$. The more recent surveys have been set up to study plankton, fish larvae and fish. In this paper we present the microplankton results from the January 2004 campaign, of particular interest because of the rarity of studies on this group in Terre Adélie and neighbouring waters. This will include the abundances and spatial distribution of the dominant taxa present, as well as the assemblages they form, in relation to the main physicalchemical parameters.

\section{Material and methods}

\section{Sampling and analyses}

The ICOTA campaign took place on-board the French R.V. Astrolabe from 19 to 31 January 2004. Prominent features along the coast are three large bays (Commonwealth, Watt and Buchanan Bays), the presence of small glaciers (the Astrolabe and the Zélée), as well as the largest glacier in the region: the Mertz Glacier. Relatively shallow waters can be found over the Adélie Bank, a large plateau ( $200 \mathrm{~m}$ depth) between the Astrolabe Glacier and Commonwealth Bay. On either side of this bank, innershelf depressions are found, most notably north of Terre Adélie and west of the Mertz Glacier. The deepest (1,200 m maximum) is known as the Adélie Depression, and is located between the Mertz Glacier and Watt Bay $\left(142^{\circ} \mathrm{E}-146^{\circ} \mathrm{E}\right)$. It is limited to the north by a sill at the edge of the shelf break. During the campaign, the water was free of sea-ice, with icebergs observed only near the glaciers. We sampled at a total of 38 stations in the waters over the continental platform between $139^{\circ} \mathrm{E}-145^{\circ} \mathrm{E}$ and $66^{\circ} \mathrm{S}-67^{\circ} \mathrm{S}$ (Fig. 1).

Throughout the survey, regular measurements of sea surface temperature (SST) and salinity (SSS) were taken with an on-board surface thermosalinometer (managed by CSIRO under the SURVOSTRAL programme) and were used to calculate sea surface density.

Water samples for each station were obtained using an 8-1 Niskin at $5 \mathrm{~m}$ depth in order to study levels of nutrients, photosynthetic pigments and the microplankton community.

Water samples for nitrate $\mathrm{NO}_{3}{ }^{-}$, nitrite $\mathrm{NO}_{2}{ }^{-}$and silicic acid $\mathrm{Si}(\mathrm{OH})_{4}(20 \mathrm{ml})$ were collected directly from the Niskin Bottles using polyethylene syringes. Polyethylene flasks were filled ca. 2/3 full, immediately frozen vertically and stored at $-20^{\circ} \mathrm{C}$ until analysis. Syringes and flasks had previously been soaked in $10 \% \mathrm{HCl}$ for $24 \mathrm{~h}$ and rinsed thrice with Milli-Q water and sample water. Nutrients were determined by means of a Technicon AutoAnalyser II. Nitrate and nitrite were analysed according to working procedures of Tréguer and Le Corre (1975), while silicate was determined according to Gordon et al. (1993). OSIL marine nutrient standards were used for calibrations.

Phytopigment analysis has been described in Swadling et al. (2008). In brief, seawater was filtered through 13-mm $\mathrm{GF} / \mathrm{F}$ filters and then frozen in liquid nitrogen for return to Australia where pigments were extracted and analysed by HPLC (Zapata et al. 2000).

Microplankton samples were obtained at each station by filtering 2-5 1 of seawater from the Niskin bottle through a $20 \mu \mathrm{m}$ mesh net. The resulting sample was rinsed into a flask and preserved in $2.5 \%$ buffered formalin for a final volume of $100 \mathrm{ml}$.

The microplankton assemblages were later studied in Belgium using an Olympus IX50 inverted microscope. Subsamples of between 10 and $15 \mathrm{ml}$ were collected and allowed to sediment in a $20 \mathrm{ml}$ chamber for at least $18 \mathrm{~h}$ and then observed using a $20 \times$ and $40 \times$ objectives. Microplankton $(>20 \mu \mathrm{m})$ were identified using the recent work published by Scott and Marchant (2005). Diatoms were identified at the genus level wherever possible. A similar in-depth identification of dinoflagellates, silicoflagellates and ciliates was not done for this study. Cells were counted and identified (to the lowest taxon possible for diatoms) in order to estimate abundances (expressed as cells $1^{-1}$ ). In the case of Thalassiothrix antarctica, a long narrow pennate diatom that was only found broken in the 
Fig. 1 Map of Terre Adélie and Georges V Land with position of sampling stations (a) and bathymetry (b)
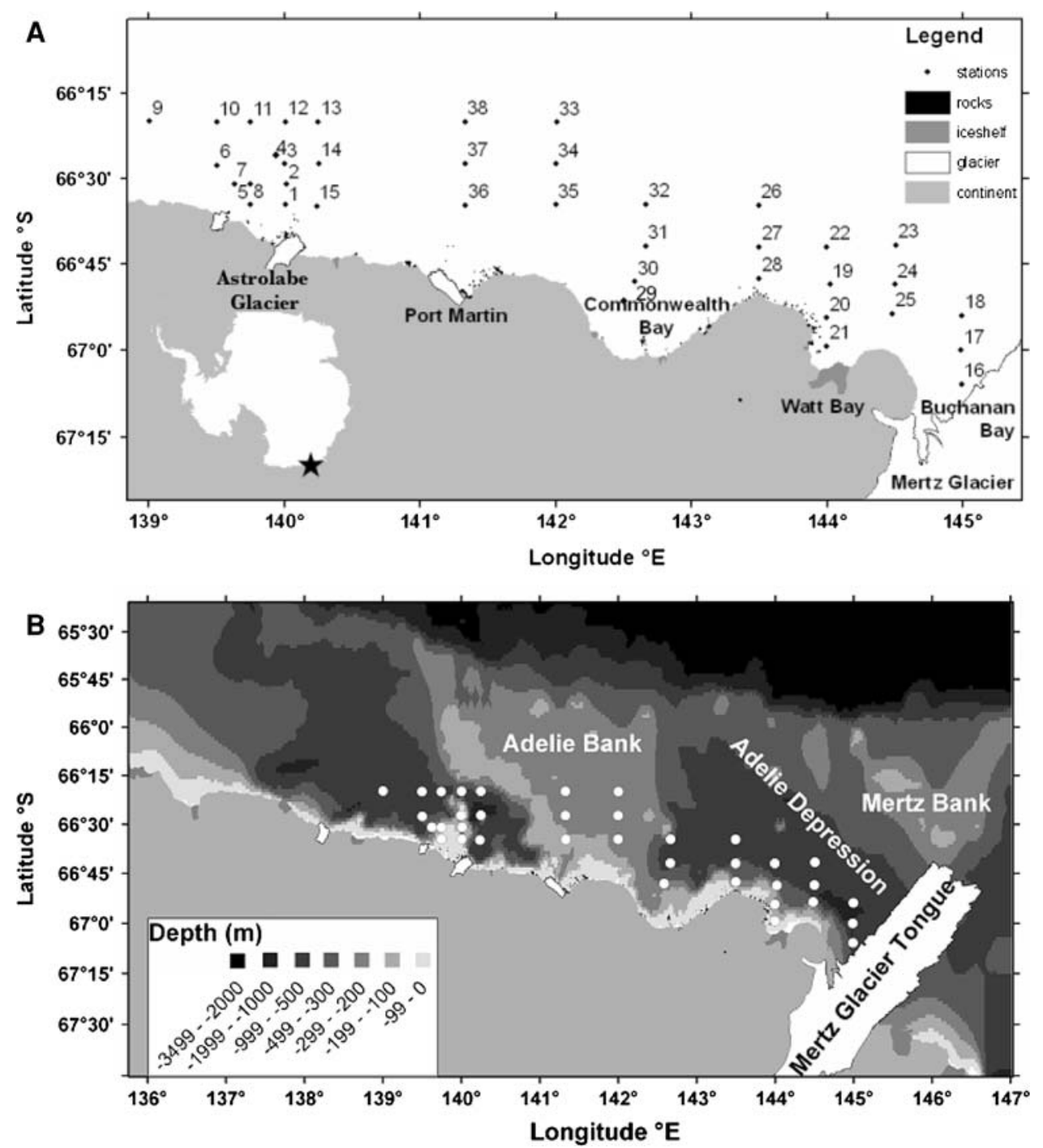

samples, only fragments $>100 \mu \mathrm{m}$ long were counted in order to limit overestimation of this species. A minimum of 100 fields per sample were counted using the $20 \times$ objective.

Community diversity based on abundances was estimated by calculating the Shannon-Weaver diversity index H' (log-base) using the BioDiversity Pro software package.

A complementary qualitative study of some samples was done in order to better identify the diatom taxa present. For this 1-ml sub-samples were filtered and rinsed with distilled water. Each filter was put on a carbon tape attached to a metal stub (25 mm diameter). Sub-samples were dried, carbon-coated and observed with a LEO (438VP) scanning electron microscope (SEM).

GIS mapping and statistical analysis

Geographic Information Systems (GIS) (ArcGis 9.1; ESRI) were used to produce distribution maps of the microplankton and environmental variables. Environmental and biological data were imported into the GIS as point georeferenced data. Interpolations of surface temperature and salinity were calculated to generate raster layers (based on pixels) by kriging using the Geostatistical Analyst extension of ArcGis. Geostatistics are methods which allow the estimation of a value at unsampled locations (Rivoirard et al. 2000). Areas where interpolations are not accurate enough are withdrawn from the map depending on the standard deviation map obtained as well when kriging is processed.

Statistical analyses were done using the Statistica (for scatter plots and relationships between diatom abundance and water surface density) and Microsoft Xlstat (for correspondence analyses) software packages. The affinity of assemblages both among sites and principal diatom taxa (square root of abundance) was established from the ( sites $\times$ taxa) matrix using a correspondence analysis. Sites and taxa groups were distinguished by automatic hierarchical classification. 


\section{Results}

Environmental variables

A density gradient was observed in surface waters over this region (Fig. 2a), following quite closely the gradient in sea surface salinities (SSS) (Fig. 2b). In general higher densities were observed closer to shore than further out to sea. Denser waters (and saltier, SSS > 34.2) were to be observed around and offshore from the Astrolabe Glacier, and east along the coast until Commonwealth Bay from where less dense (and fresher, SSS < 33.9) waters predominated towards the Mertz Glacier and further offshore. Waters were coldest (SST $<-1^{\circ} \mathrm{C}$ ) in the proximity of the Mertz Glacier, whereas relatively warm waters were observed over the plateau ( $\left.\mathrm{SST}>0.2^{\circ} \mathrm{C}\right)$ (Fig. 2c).

\section{Nutrients}

Nutrients measured, nitrate $\mathrm{NO}_{3}{ }^{-}$, nitrite $\mathrm{NO}_{2}{ }^{-}$, and silicic acid $\mathrm{Si}(\mathrm{OH})_{4}$, showed (Fig. 3a-c) variations throughout the site. At $5 \mathrm{~m}$ depth, both $\mathrm{NO}_{3}{ }^{-}$and $\mathrm{SiO}_{3}^{2-}$ showed a gradient from higher concentrations in the west (maxima of $34.4 \mu \mathrm{M}$ at station 8 and $56.1 \mu \mathrm{M}$ at station 5 , respectively) to lower ones over the Adélie Bank and the Adélie Depression (minima of $30.4 \mu \mathrm{M}$ at station 16 and $50.2 \mu \mathrm{M}$ at station 31, respectively). $\mathrm{NO}_{2}{ }^{-}$on the other hand, showed highest concentrations over the Adélie Bank (0.24 $\mu \mathrm{M}$ at station 33$)$, with values slightly decreasing both to the east and west of this area (minimum of $0.15 \mu \mathrm{M}$ at station 7).

\section{Chl $a$}

Chlorophyll concentrations (Fig. 4) were highest near the Astrolabe and Mertz Glaciers and over the Adélie Depression, with a maximum near the Mertz Glacier (1.57 $\mathrm{g} \mathrm{I}^{-1}$ at station 16). Much lower values were observed over the plateau (minimum $0.21 \mu \mathrm{g} \mathrm{l}^{-1}$ at station 35). Vertically, there was little variation in concentrations in the waters surrounding the Astrolabe Glacier, whereas in the eastern region concentrations dropped considerably with depth.

\section{Microplankton}

Microplankton abundances varied widely. Total microplankton abundances averaged $11,754 \pm 15,312$ cells $1^{-1}$ with a maximum of 71,154 cells $1^{-1}$ (station 23) over the Adélie Depression. Values then decreased towards the coast and the west, with a minimum of 417 cells $1^{-1}$ (station 9) in the westernmost region. The Shannon index H' values were minimal near the Mertz Glacier and over the
Adélie Depression (0.12 in stations 17 and 23) but then increased towards the west with a maximum of 1.01 near the Astrolabe Glacier (station 2) and varied little in the surrounding waters or over the Adélie Bank.

From Terre Adélie to the Mertz Glacier, the microplankton community (Fig. 5) was completely dominated by diatoms (ranging from 394 to 70,274 cells $1^{-1}$ ), with abundances 1-2 orders of magnitude greater than the other components: dinoflagellates $\left(0-624\right.$ cells $\left.1^{-1}\right)$, silicoflagellates $\left(0-460\right.$ cells $\left.1^{-1}\right)$ and ciliates $\left(0-628\right.$ cells $\left.1^{-1}\right)$.

Non-diatom microplankton

Dinoflagellates identified included members of the genera Dinophysis, Gymnodinium, Gonyaulax and Protoperidinium. Results from dinoflagellates (Fig. 5a) have all been pooled into a single category with an average of $218 \pm 178$ cells $1^{-1}$. In general, higher concentrations of dinoflagellates were seen close to shore in Commonwealth Bay and over the Adélie Depression (with a maximum of

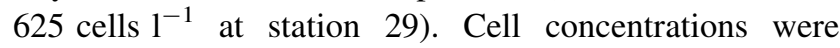
lowest away from the coast, west of the Astrolabe Glacier (indeed, no dinoflagellates were observed in several samples from this area).

Silicoflagellates (Fig. 5b) presented the lowest abundances of all the microplankton, $35 \pm 86$ cells. $^{-1}$, except in the waters just west of the Astrolabe Glacier (maximum of 460 cells $1^{-1}$ at station 6) where they frequently outnumbered dinoflagellates and ciliates. Their numbers decreased drastically towards the east (absent from several samples). Dictyocha speculum was the only silicoflagellate species observed.

A large majority of the ciliates observed during this study were tintinnids ( $71.6 \pm 32 \%$ of all ciliates), amongst which the genus Codonellopsis was abundant. At $5 \mathrm{~m}$, ciliates averaged $102 \pm 126$ cells $l^{-1}$, higher levels were observed just off the Astrolabe (with a maximum of 628 cells $1^{-1}$ at station 2) and Mertz Glaciers (in particular over the Adélie Depression), and then lower over the Adélie Bank (Fig. 5c). There were several samples in which no ciliates were observed.

Diatom abundances and species composition

As stated previously, diatoms were the overwhelmingly dominant component of the microplankton community. Results at $5 \mathrm{~m}$ depth (Fig. 5d), averaging 11,398 \pm 15,161 cells $1^{-1}$, showed large variations over the area surveyed, with very high abundances observed over the Adélie Depression (maximum of 70,275 cells $1^{-1}$ at station 23) and generally in the waters neighbouring the Mertz Glacier, whereas in waters over the Adélie Bank and the western part of the region the diatom population showed a 
Fig. 2 Sea-surface (a) density, (b) salinity and (c) temperature $\left({ }^{\circ} \mathrm{C}\right)$ in Terre Adélie and Georges V Land (from continuous measurements at $3 \mathrm{~m} \mathrm{depth)}$
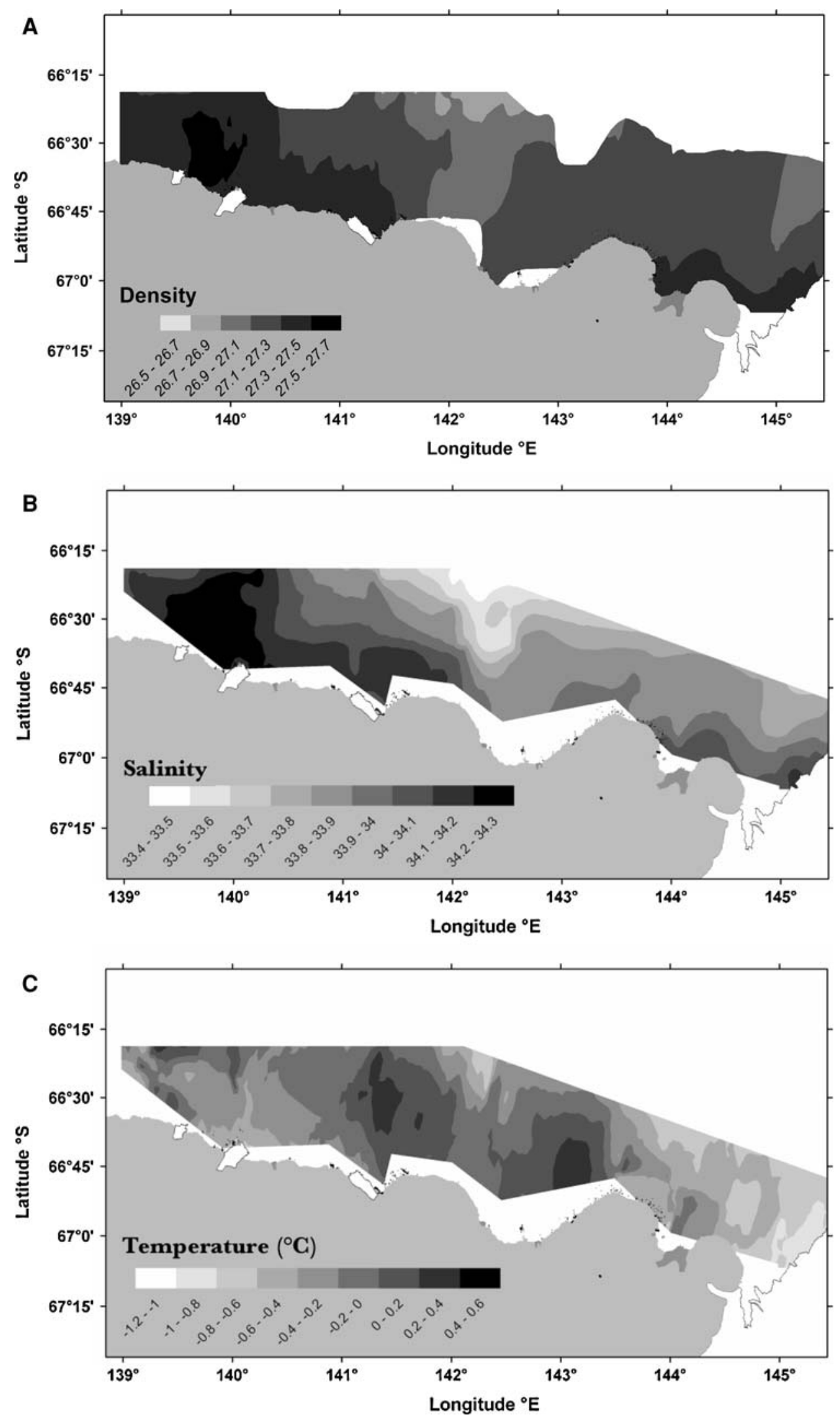
Fig. 3 Nutrient concentrations $(\mu \mathrm{M})$ at $5 \mathrm{~m}$ depth. a Nitrite $\mathrm{NO}_{2}{ }^{-}, \mathbf{b}$ nitrate $\mathrm{NO}_{3}{ }^{-}$, $\mathbf{c}$ silicic acid $\mathrm{Si}(\mathrm{OH})_{4}$
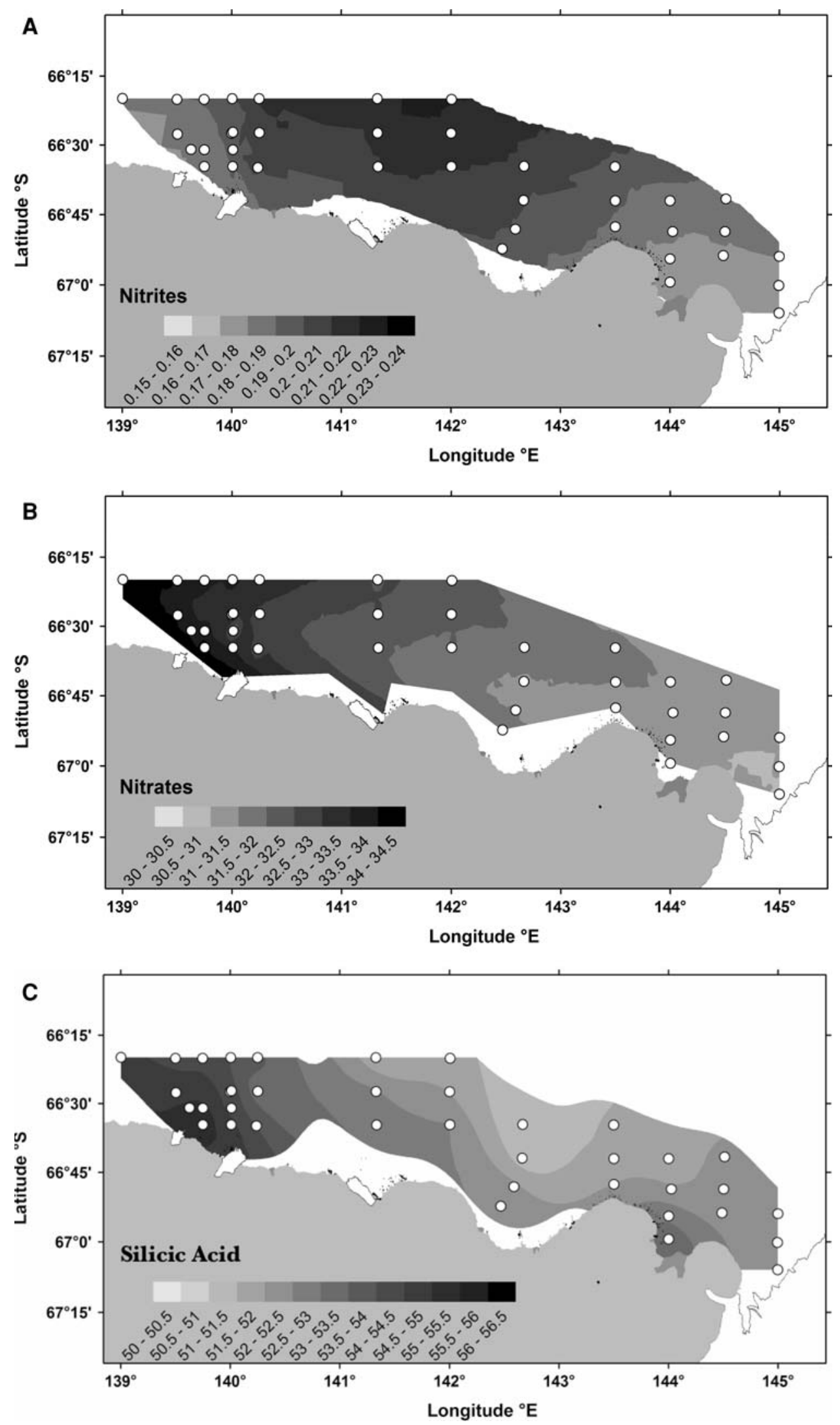
Fig. 4 Total Chl $a$ concentrations $\mu \mathrm{g} 1^{-1}$ at $5 \mathrm{~m}$ depth

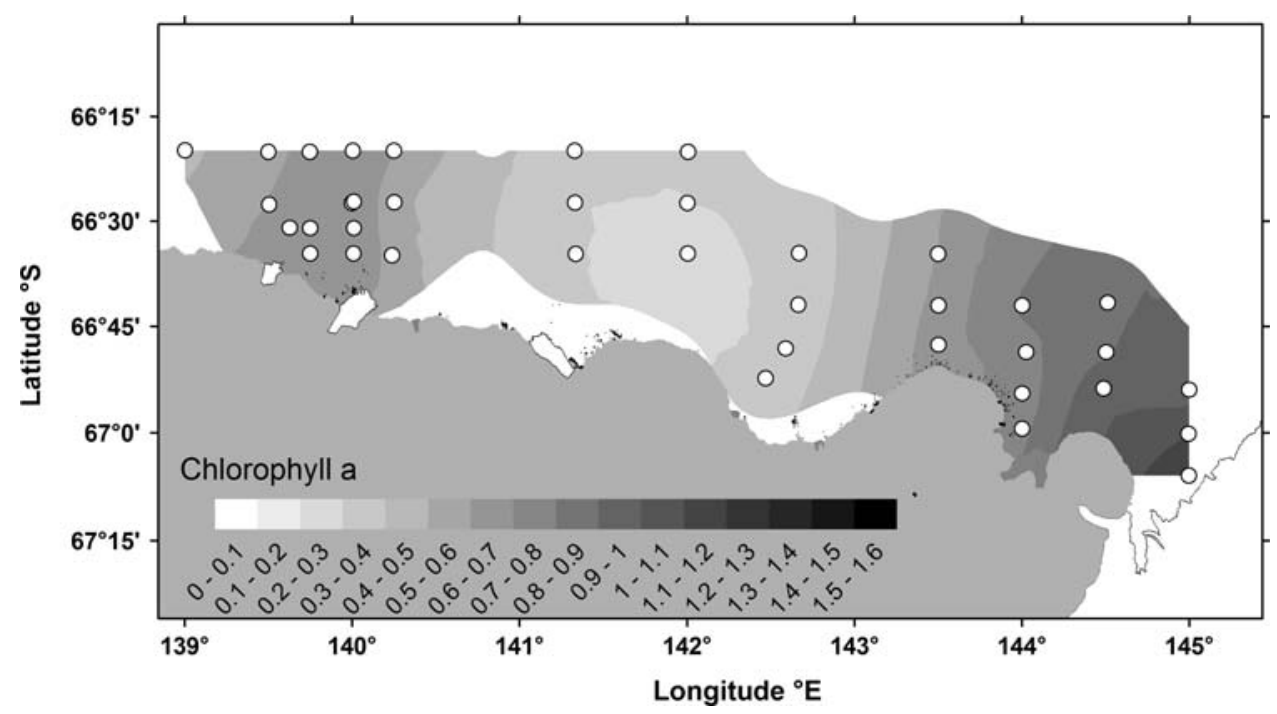

marked decrease in numbers (minimum of 48 cells $1^{-1}$ at station 38).

The most common diatom species, counted and identified using optical microscopy, are listed in Table 1, along with their frequency of occurrence. Among the most widespread groups, only four ever individually constituted more than $10 \%$ of the diatom population at more than one station and could be considered a dominant group. These were Fragilariopsis spp., Chaetoceros criophilus, Rhizosolenia spp. and Corethron pennatum (Fig. 6). Occasionally, Thalassiothrix antarctica also approximated this $10 \%$ level. The use of SEM allowed to identify other diatom species that were not included in the counts. Among these were the centric diatoms, Chaetoceros atlanticus, Coscinodiscus bouvet, Stellarima microtrias, several Thalassiosira species (such as T. ritscheri, T. lentiginosa, T. gravida, T. gracilis, T. tumida, T. ritscheri), Porosira glacialis, Asteromphalus hookeri, Actinocyclus actinochilus, Rhizosolenia antennata and the pennate diatoms, Achnanthes vicentri, and Cocconeis spp., as well as several Fragilariopsis species (such as F. kerguelensis, F. curta, F. pseudonana, F. rhombica).

The small, rectangular-shaped, colonial pennate diatom Fragilariopsis spp. (sizes approximately $5 \times 30 \mu \mathrm{m}$, with occasional larger forms reaching up to $8 \times 100 \mu \mathrm{m}$ ) was by far the most widely distributed and abundant group (Fig. 7a). Abundances (often an order of magnitude greater than other groups) varied a lot throughout the zone, with an average of 9,335 $\pm 15,170$ cells $1^{-1}$ and a maximum of 68 222 cells $1^{-1}$ at station 23. Generally Fragilariopsis spp. comprised $>80 \%$ of the diatoms (ranging from 60 to $90 \%$ ), in the eastern region of our site, in particular over the Adélie Depression. In the western region, although they frequently remained abundant (but an order of magnitude less), they were no longer as dominant (ranging from 0 to
$50 \%$ of diatoms) due to the large number of other species present. None were observed in two offshore stations (10 and 11).

The chain-forming centric diatom Chaetoceros criophilus $(\sim 25 \times 30 \mu \mathrm{m})$ was also present throughout the region (Fig. 7b), with an average abundance of $478 \pm$ 422 cells $1^{-1}$. Chaetoceros criophilus was most abundant close to the coast over the Adélie Bank (maximum of 1,701 cells $1^{-1}$ at station 36) and near the Astrolabe Glacier (peak of 1,344 cells $1^{-1}$ at station 6). Further offshore and to the east, abundances decreased, to the point that none were observed at certain stations (16, 17 and 25). Several other Chaetoceros species were observed (Table 1), but the only other one to reach relatively high abundances was $C$. dichaeta $\left(51 \pm 54\right.$ cells $\left.1^{-1}\right)$.

The centric diatoms Rhizosolenia spp. and Corethron pennatum, with sizes ranging from $5 \times 140$ to $40 \times 500 \mu \mathrm{m}$ and $20 \times 90$ to $50 \times 350 \mu \mathrm{m}$, respectively, were two of the largest species present (apart from a few Thalassiossira spp. of $\varnothing>100 \mu \mathrm{m}$ ). They showed similar distributions and abundances (Fig. 7c, d), averaging $378 \pm 359$ cells $^{-1}$ and $206 \pm 281$ cells $1^{-1}$, respectively, and were frequently dominant species in the western part of the area (maximum $24.3 \%$ of all diatoms for Rhizosolenia spp. and $31.3 \%$ for C. pennatum). Both groups showed their highest abundances close to the Astrolabe Glacier $\left(1,841\right.$ cells $^{-1}$ for Rhizosolenia spp. at station 6 and 1,395 cells $1^{-1}$ for $C$. pennatum at station 2), but where Rhizosolenia spp. distribution seemed to remain close to the coastline, continuing eastward a bit over the Adélie Bank, $C$. pennatum abundances peaked directly to the north of the Astrolabe Glacier. Over the bank, Rhizosolenia spp. could constitute approximately $10 \%$ of the diatom population, whereas in this same area $C$. pennatum was always below $10 \%$. Both groups were occasionally present in the 
Fig. 5 Microplankton

abundances (cells $1^{-1}$ ) at $5 \mathrm{~m}$ depth. a dinoflagellates,

b silicoflagellates, c ciliates, d diatoms
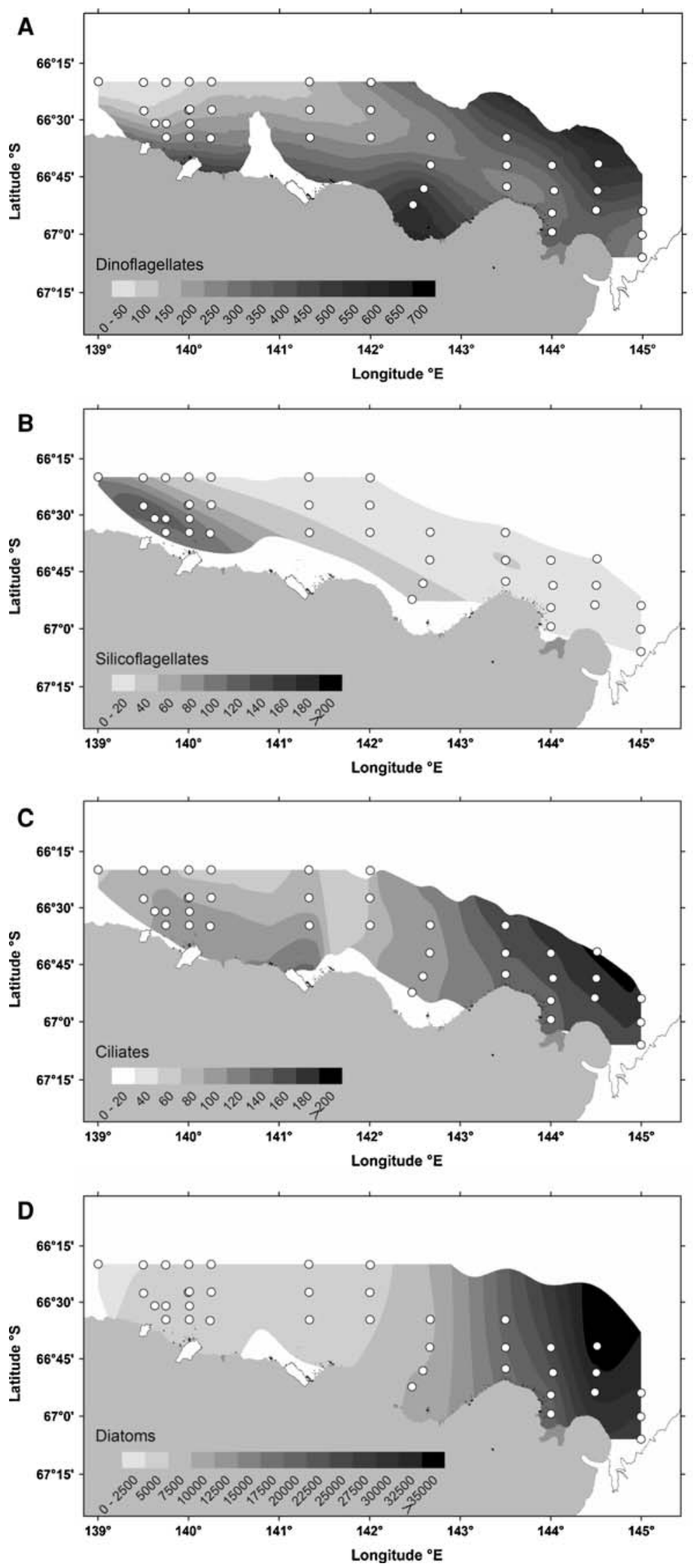
Table 1 Frequency of occurrence (FO) of common diatom species found in samples (all depths) from Terre Adélie to the Mertz Glacier

\begin{tabular}{lc}
\hline Taxon & FO $(\%)$ \\
\hline Actinocyclus spp. & 98.9 \\
Thalassiothrix antarcticum & 97.1 \\
Fragilariopsis spp. & 96.6 \\
Rhizosolenia spp. & 96.6 \\
Thalassiosira spp. & 91.4 \\
Chaetoceros spp. & 90.2 \\
Chaetoceros criophilus & 88.5 \\
Corethron pennatum & 88.5 \\
Asteromphalus spp. & 72.4 \\
Nitzschia, Pseudo-nitzschia, Navicula group & 67.8 \\
Chaetoceros dichaeta & 61.5 \\
Coscinodiscus spp. & 41.4 \\
Eucampia antarctica & 33.9 \\
Banquisia belgica & 25.3 \\
Odontella spp. & 14.9 \\
Chaetoceros curvisetus & 9.2 \\
\hline
\end{tabular}

east, but were rare (between 0.3 and $7 \%$ of diatoms for Rhizosolenia spp. and 0-1\% for C. pennatum).

Thalassiothrix antarctica was quite abundant in certain areas (albeit to a lesser degree than the four groups mentioned previously), sometimes representing $>10 \%$ of the diatom population over the Adélie Bank. The average abundance was $236 \pm 191$ fragments $1^{-1}$, with a rather uniform distribution throughout the region, except for peaks of abundance close to shore near the Astrolabe Glacier and at either side of Watt Bay (maximum of 755 fragments $1^{-1}$ at station 28).

Two ice associated species were also counted: Eucampia antarctica and Odontella sp. Odontella sp. was extremely rare $\left(2.8 \pm 8\right.$ cells $1^{-1}$ at $\left.5 \mathrm{~m}\right)$, but could have been underestimated due to the difficulty of observing its weakly silicified cells with the optical microscope. It was more noticeably present near the Astrolabe Glacier. Eucampia antarctica averaged $8.3 \pm 24$ cells $1^{-1}$ and was most abundant near the Astrolabe Glacier (maximum 127 cells $^{-1}$ at station 1 ) as well as to a lesser degree near the Mertz Glacier. In the former region it comprised up to $3 \%$ of the diatom population.

\section{Diatom assemblages}

Correspondence analysis was done on the abundances of the principal diatom taxa at $5 \mathrm{~m}$ depth (Fig. 8). The first two axes accounted for $90.7 \%$ of the variation. These results allowed similar stations to be gathered into three groups, each characterised by the dominance of a certain taxon. The first axis, which accounted for $77.66 \%$ of the variation, shows a clear separation of the stations in the Mertz Glacier and Adélie Depression region (stations 16, $17,18,19,20,21,24,25,27)$ as well as the two coastal Commonwealth Bay stations (29 and 30) from the rest of the study area. In this group Fragilariopsis spp. is the overwhelmingly abundant and dominant taxon. The second axis (13.04\% of the variation) allows for the separation of the Adélie Bank stations (15, 31, 32, 33, 34, 35, 36, 38) from those near the Astrolabe Glacier and further east (1, 2, $3,6,7,10,11,13)$. The Adélie Bank group appears to have been determined by the presence of Chaetoceros criophilus, whereas the Astrolabe Glacier group was determined by the larger species Corethron pennatum and Rhizosolenia spp. Based on this grouping of stations, average abundances of the main microplankton groups for each zone have been presented in Table 2 .

Diatoms and water surface densities

We compared the distribution at $5 \mathrm{~m}$ depth of the four dominant taxa observed in this study (Corethron pennatum, Rhizosolenia spp., Chaetoceros criophilus and Fragilariopsis spp.) with the surface water densities (Fig. 9). For this we did a correlation between diatom abundances and density values at each station. Fragilariopsis spp. (Fig. 9a) showed a distinct preference for stratified waters with a lower surface density. Although present throughout the region, Fragilariopsis spp. abundances exploded within a limited range of surface water densities: between 27.2 and 27.3.

Corethron pennatum and Rhizosolenia spp. (Fig. 9b) also showed a clear relationship with surface water densities $(P<0.01)$, but in their case we observe a marked preference for more mixed waters with higher surface densities.

Chaetoceros criophilus (Fig. 9b), on the other hand, does not have a significante relationship with surface water density $(P=0.9)$, although its highest abundances were observed in waters with intermediate surface densities.

\section{Discussion}

Although certain studies (Reay et al. 2001) have shown water temperature to influence phytoplankton production, it does not seem to have been a deciding factor in our region as the coldest waters (around the Mertz Glacier and Adélie Depression) are those that show the highest abundances and biomass. This could be due to the low variation in temperatures present in our region (barely $1.5^{\circ}$ ), or to the higher influence of other factors, such as the water column stability as estimated by surface water densities (higher 
Fig. 6 Principal diatoms from Terre Adélie and the Mertz Glacier region. Photos taken with an inverted microscope (a, $\mathbf{c}, \mathbf{e}, \mathbf{g}$ by C.Beans) and a scanning electron microscope (b, $\mathbf{d}, \mathbf{f}, \mathbf{h}$ by C.Vallet \& L.Courcot). a, b Fragilariopsis spp.; c, d Chaetoceros criophilus; e, f Rhizosolenia spp.; $\mathbf{g}$, h Corethron pennatum. Magnification for SEM photos, objective used for inverted microscope photos are specified
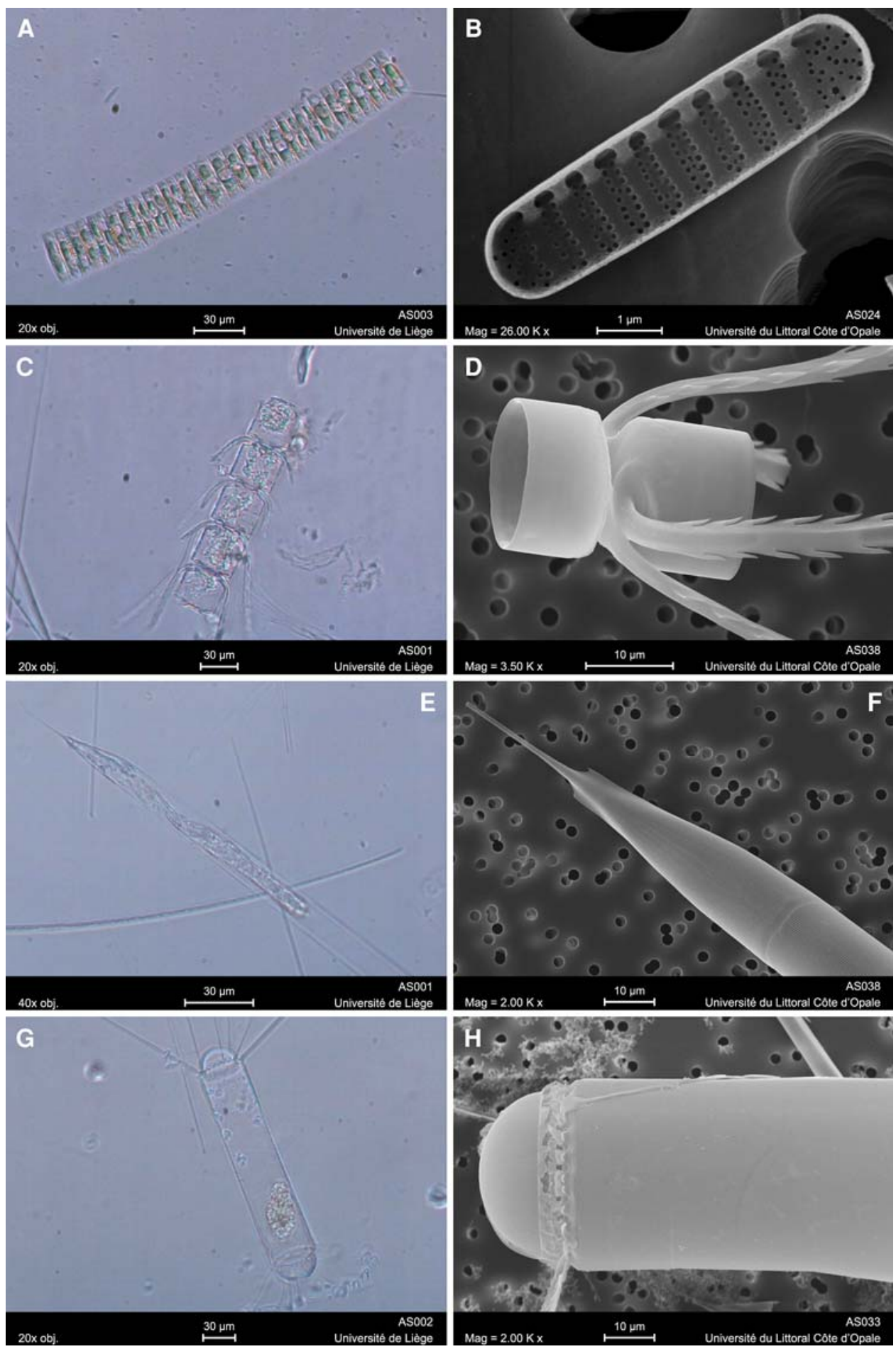

abundances and biomass were observed in the more stable waters of the Mertz Glacier region).

With chlorophyll $a$ concentrations averaging $0.64 \mu \mathrm{g}^{-1}$ at $5 \mathrm{~m}$ depth, and ranging between 0.04 and $1.57 \mu \mathrm{g} \mathrm{l}^{-1}$ throughout the zone (at all depths), the waters from Terre Adélie to the Mertz Glacier appear to support a significant summer standing crop of phytoplankton, comparable to the $0.6 \mu \mathrm{g} \mathrm{l}^{-1}$ average in Antarctic waters (Table 3). Although it could be possible that we missed the peak of the summer bloom, similar levels were presented by Arrigo and van Dijken 2003, Sambrotto et al. (2003) and Vaillancourt et al. (2003) at the peak of the blooms in the Dumont d'Urville Polynya, Commonwealth Bay and the Mertz Polynya. Nevertheless, although presenting similar diatom cell abundances to neighbouring regions (Table 3), these values are lower than those observed in the coastal waters of 
Fig. 7 Abundances (cells $1^{-1}$ ) of dominant diatoms at $5 \mathrm{~m}$ depth: a Fragilariopsis spp., b Chaetoceros criophilus,

c Rhizosolenia spp.,

d Corethron pennatum
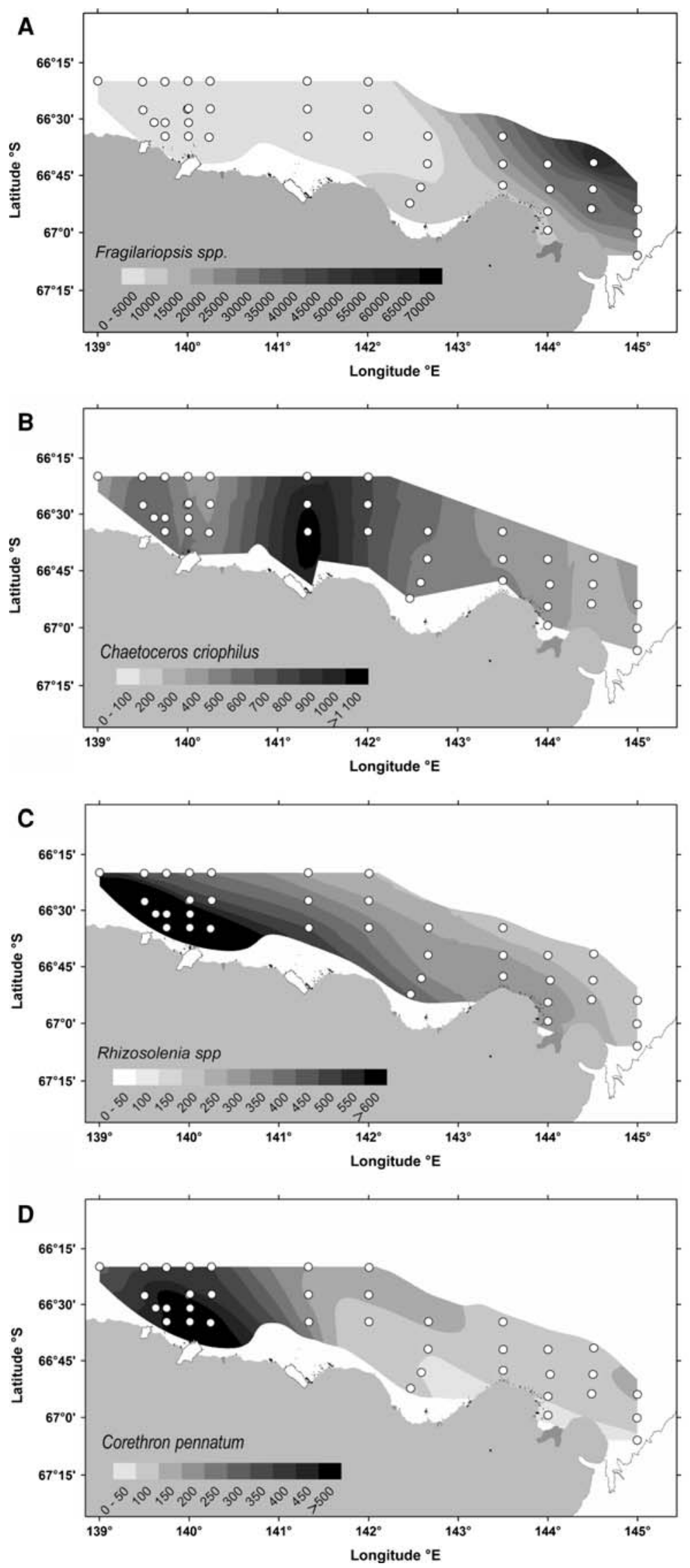
Fig. 8 Correspondence analysis of dominant diatom groups at $5 \mathrm{~m}$ depth and sampling stations

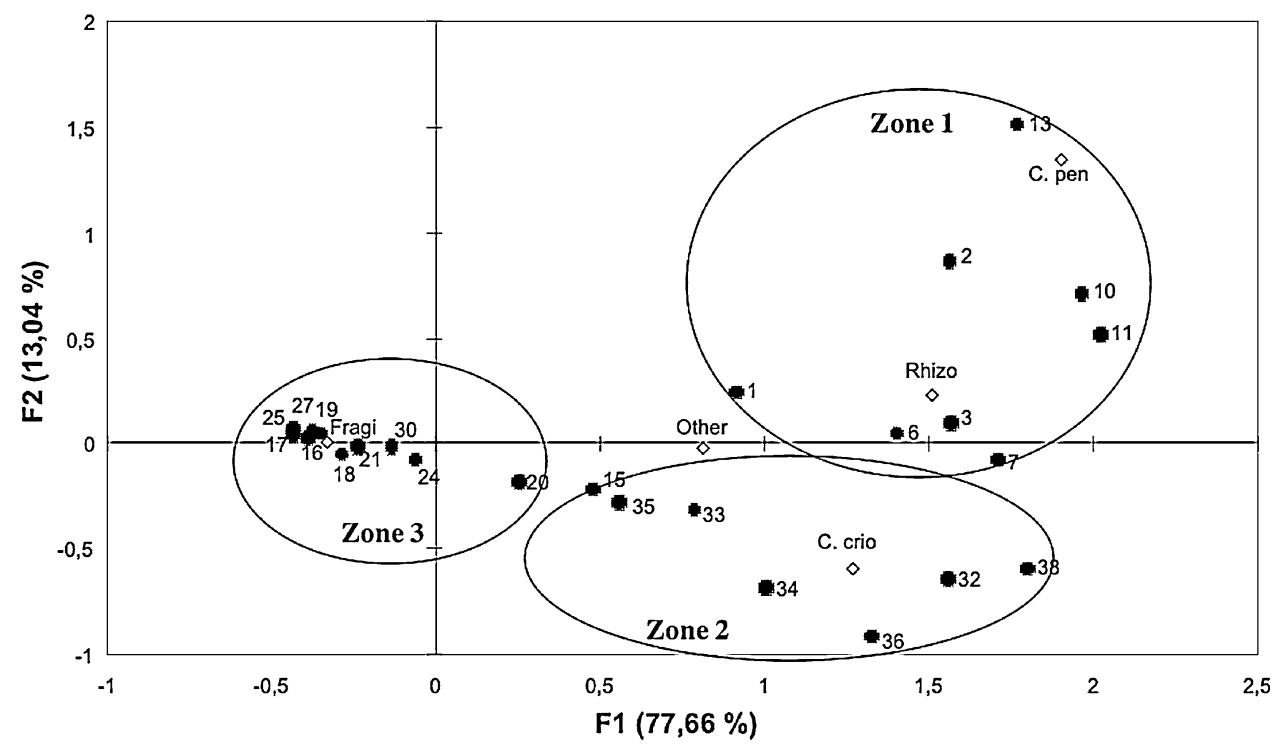

Prydz Bay $\left(2.1 \mu \mathrm{g}^{-1}\right)$ (Jacques and Fukuchi 1994) and Terra Nova Bay (0.1-4 $\mu \mathrm{g}^{-1}$ ) (Goffart et al. 2000). Also, in a major survey of the region, Wright and van den Enden (2000) found that waters from $128^{\circ} \mathrm{E}$ to $150^{\circ} \mathrm{E}$ were considerably less productive than waters from $93^{\circ} \mathrm{E}$ to $120^{\circ} \mathrm{E}$.
It appears then that phytoplankton biomasses are lower in the Terre Adélie-George V Lands than in those neighbouring regions. The $\mathrm{Chl} a$ concentrations measured during this study were higher than those of the waters north of the Terre Adélie shelf break (yet still south of the Polar Front)

Table 2 Nutrients $(\mu \mathrm{M})$, Chl $a\left(\mu \mathrm{g}^{-1}\right)$, microplankton (cells ${ }^{-1}$ ) and Shannon-Weaver diversity index $H^{\prime}$ in Terre Adélie and Georges V Land surface waters (5 m depth) (average $\pm \mathrm{SD}$, maximum-minimum)

\begin{tabular}{|c|c|c|c|}
\hline & Astrolabe Glacier & Adélie Bank & Mertz Glacier + Adélie Depression \\
\hline Nitrite & $0.19 \pm 0.02(0.15-0.22)$ & $0.21 \pm 0.01(0.19-0.24)$ & $0.19 \pm 0.02(0.16-0.22)$ \\
\hline Nitrate & $33.45 \pm 0.84(31.65-34.37)$ & $32.22 \pm 0.4(31.38-32.64)$ & $31.29 \pm 0.48(30.38-31.91)$ \\
\hline Silicic Acid & $54.42 \pm 1.05(51.51-58.08)$ & $51.81 \pm 1.21(50.22-53.23)$ & $52.23 \pm 0.80(51.15-54.21)$ \\
\hline Chl $a$ & $0.68 \pm 0.14(0.38-0.94)$ & $0.29 \pm 0.05(0.21-0.35)$ & $0.79 \pm 0.37(0.28-1.57)$ \\
\hline Ciliates & $80 \pm 180(0-628)$ & $42 \pm 30(14-97)$ & $156 \pm 82(40-312)$ \\
\hline Dinoflagellates & $102 \pm 105(0-352)$ & $154 \pm 82(61-269)$ & $354 \pm 180(78-624)$ \\
\hline Silicoflagellates & $71 \pm 139(0-460)$ & $12 \pm 12(0-35)$ & $17 \pm 22(0-67)$ \\
\hline Diatoms & $3,317 \pm 2,790(394-9,058)$ & $3,360 \pm 1,271(1,190-5,432)$ & $22,919 \pm 18,249(6,507-70,274)$ \\
\hline Fragilariopsis spp. & $954 \pm 1,346(0-3,669)$ & $1216 \pm 850(76-2,459)$ & $21,159 \pm 18,064(4,448-68,222)$ \\
\hline Rhizosolenia spp. & $608 \pm 516(56-1,841)$ & $298 \pm 142(145-555)$ & $226 \pm 115(76-456)$ \\
\hline Corethron pennatum & $433 \pm 380(72-1395)$ & $107 \pm 64(0-183)$ & $70 \pm 53(0-187)$ \\
\hline Chaetoceros criophilus & $444 \pm 380(72-1395)$ & $821 \pm 488(168-1,701)$ & $312 \pm 331(0-989)$ \\
\hline Other Chaetoceros spp. & $311 \pm 307(18-973)$ & $385 \pm 331(139-1,463)$ & $434 \pm 356(34-1,145)$ \\
\hline Thalassiothrix antarctica (fragments/l) & $204 \pm 215(0-696)$ & $171 \pm 123(42-425)$ & $300 \pm 193(96-755)$ \\
\hline Eucampia antarctica & $12 \pm 36(0-127)$ & 0 & $10 \pm 15(0-44)$ \\
\hline Asteromphalus spp. & $37 \pm 54(0-175)$ & $58 \pm 66(0-208)$ & $81 \pm 54(0-160)$ \\
\hline Acinocyclus spp. & $97 \pm 96(0-316)$ & $101 \pm 63(17-215)$ & $139 \pm 84(16-323)$ \\
\hline Thalassiosira spp. & $69 \pm 95(0-337)$ & $41 \pm 34(0-97)$ & $61 \pm 42(0-161)$ \\
\hline Coscinodiscus spp. & $16 \pm 33(0-105)$ & $8 \pm 11(0-28)$ & $11 \pm 15(0-54)$ \\
\hline Odontella spp. & $6 \pm 13(0-37)$ & 0 & $1 \pm 5(0-18)$ \\
\hline Nitzschia/Pseudo-nitzschia group & $6 \pm 21(0-74)$ & 0 & 0 \\
\hline Other diatoms & $120 \pm 130(0-337)$ & $107 \pm 109(0-334)$ & $164 \pm 110(0-418)$ \\
\hline$H^{\prime}$ & $0.85 \pm 0.08(0.74-1.01)$ & $0.3 \pm 0.19(0.12-0.63)$ & $0.31 \pm 0.17(0.12-0.63)$ \\
\hline
\end{tabular}


Fig. 9 Surface water density (sigmaT) vs. abundances of four diatom species at $5 \mathrm{~m}$ depth: a Fragilariopsis spp. and b Chaetoceros criophilus, Rhizosolenia spp. and Corethron pennatum
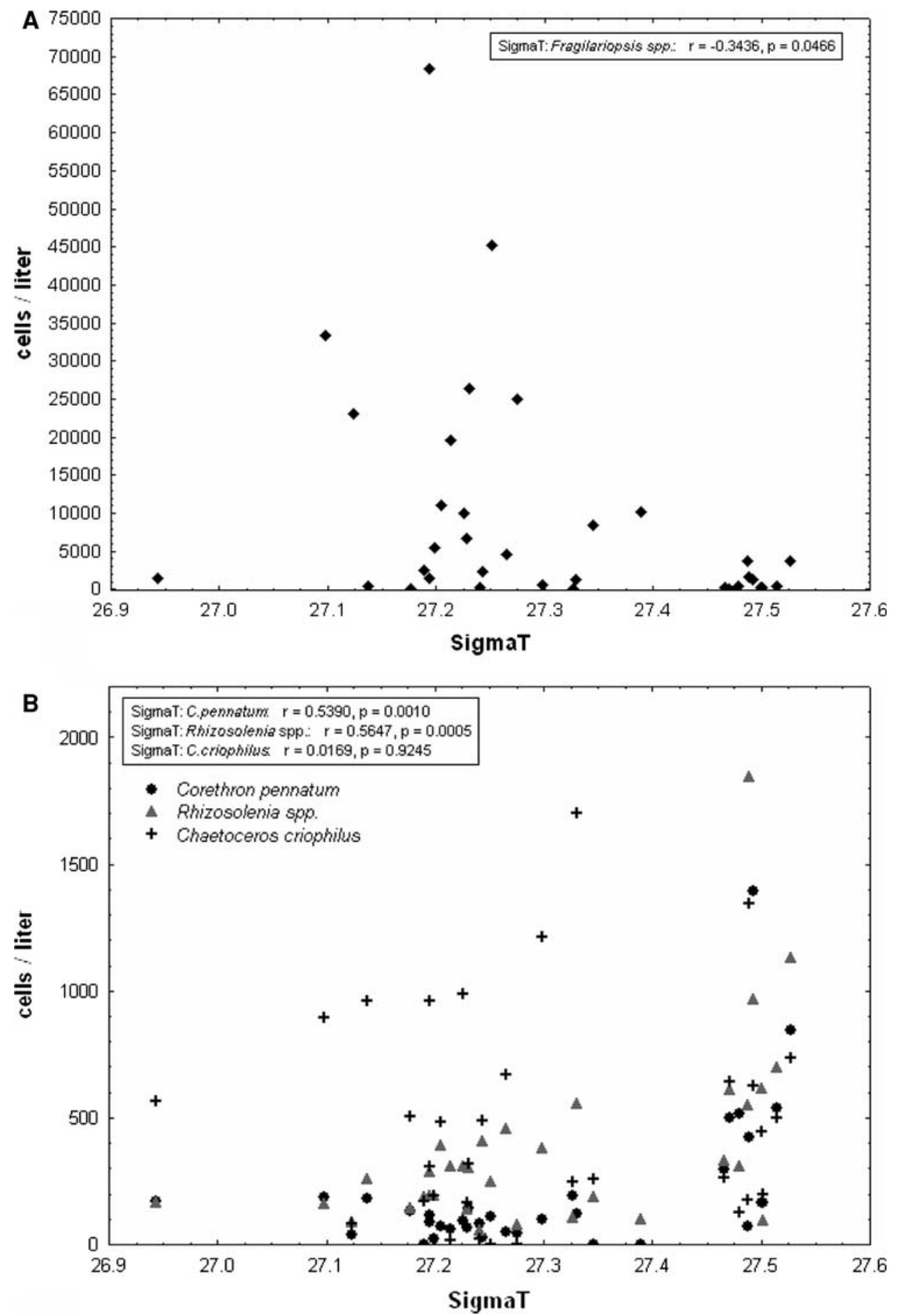

as studied by Chiba et al. in 1996 (2000) and Gomi et al. in 2000 (2005) (Table 3), indicating that the shelf waters remain an important location for primary production in the region.

As in other regions around Antarctica (Jacques and Fukuchi 1994; Chiba et al. 2000; Waters et al. 2000; Fonda Umani et al. 2005), the microplankton communities in Terre Adélie are strongly dominated by diatoms (over $80 \%$ of the microplankton). Within this group, the dominance of pennate diatoms (in particular Fragilariopsis spp.) is consistent with other eastern Antarctic and Ross Sea studies (Kopczynska et al. 1986; Goffart et al. 2000; Waters et al. 2000). Previous studies in the waters just north of the shelf break also noted the importance of Fragilariopsis spp. and related species in the region, with abundances similar to those reported here $\left(0-6.8 \times 10^{5}\right.$ cells $1^{-1}$ at 
Table $3 \mathrm{Chl} a$ and microplankton abundances in the region

\begin{tabular}{|c|c|c|c|c|}
\hline Location & Period & $\begin{array}{l}\text { Chl } a \\
\left(\mu \mathrm{g}^{-1}\right)\end{array}$ & $\begin{array}{l}\text { Diatom } \\
\text { abundances } \\
\left(\text { cells } 1^{-1} \text { ) }\right.\end{array}$ & Reference \\
\hline $\begin{array}{l}\text { Southern Ocean average } \\
\text { (BIOMASS cruises) }\end{array}$ & Summer & 0.6 & & El-Sayed (2005) \\
\hline Prydz Bay & Summer & 2.1 & & Jacques and Fukuchi (1994) \\
\hline Terre Adélie + Georges V Land & January 2004 & $0.21-1.57$ & $1.14 \times 10^{5}$ & This study \\
\hline Dumont d'Urville Polynya & November 1995 & 0.69 & $2 \times 10^{3}$ & Riaux-Gobin et al. $(2000,2003)$ \\
\hline Dumont d'Urville Polynya & Summer peak & 1.17 & & Arrigo and van Dijken, (2003) \\
\hline Mertz Polynya & & 0.93 & & \\
\hline $\begin{array}{l}\text { Terre Adélie + Commonwealth } \\
\text { Bay }\end{array}$ & December 2000-January 2001 & $\begin{array}{l}1.33 \\
1.03\end{array}$ & & $\begin{array}{l}\text { Sambrotto et al. (2003) and } \\
\text { Vaillancourt et al. (2003) }\end{array}$ \\
\hline \multicolumn{5}{|l|}{ Mertz Region } \\
\hline Terre Adélie-offshore & January-February 1996 & $0.4-0.6$ & & Chiba et al. (2000) \\
\hline Terre Adélie-offshore & February-March 2000 & $0.3-0.5$ & & Gomi et al. (2005) \\
\hline Terra Nova Bay (Ross Sea) & January-February 1998 & & Maximum $6 \times 10^{5}$ & Fonda Umani et al. (2005) \\
\hline Western Ross Sea & January 1990 & $0.1-4$ & & Goffart et al. (2000) \\
\hline
\end{tabular}

$5 \mathrm{~m}$ ): in Gomi's study (2005) the dominant diatoms were Fragilariopsis spp. $\left(0.5-1 \times 10^{5}\right.$ cells $\left.1^{-1}\right)$; Waters et al. (2000) noted the most frequent diatoms in our zone were a group composed of F. curta, Nitzschia lecontei and other related species larger than $20 \mu \mathrm{m}\left(3.6 \times 10^{4}\right.$ to $5.6 \times 10^{5}$ cells $\left.1^{-1}\right)$, while in the Terre Adélie waters close to the Polar Front (Chiba et al. 2000), the dominant diatom was F. kerguelensis. These authors also mentioned the presence of Corethron pennatum, Rhizosolenia spp. and the frequently abundant Thalassiothrix antarctica and Chaetoceros criophilus, which are all abundant species in our study.

Both the cartographic representations and the correspondence analysis done on the abundances of the principal diatom species allowed us to distinguish three separate zones in our region (Fig. 10): the Mertz Glacier and Adélie Depression zone, the Adélie Bank zone and the Astrolabe Glacier zone.

Beginning in the East, the Mertz Glacier and Adélie Depression stations are shown to be very different from the remaining zones. The region (Zone 3 in Fig. 10) is characterised by the presence of a polynya which begins to open in mid-September and is usually fully developed by mid-October, allowing for a phytoplankton bloom early in the season (Sambrotto et al. 2003; Vaillancourt et al. 2003). During our study we found there was maximum depletion of nutrients in this region and a stratified water column, probably due to the ice melt. Stratified
Fig. 10 schematic representation of the differences between the three zones

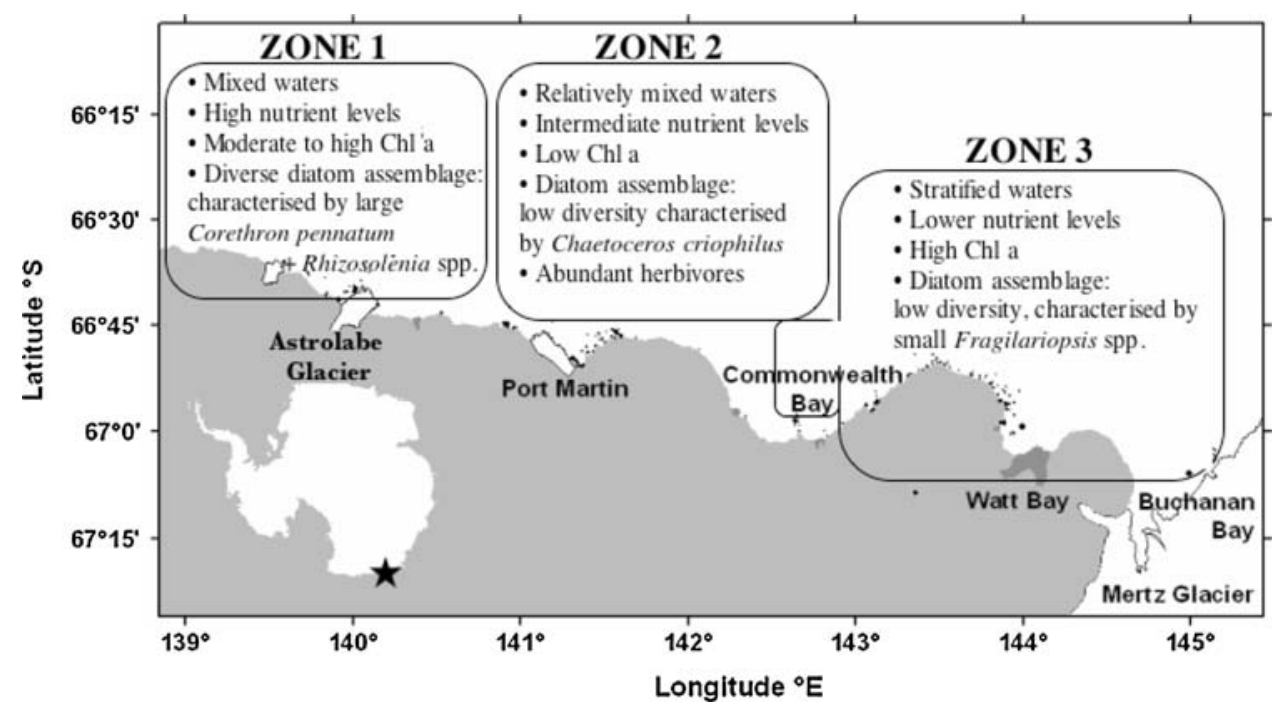


waters have been previously observed to be locations of high phytoplankton biomass (Priddle et al. 1994). The nutrient depletion would appear to indicate that the bloom had begun earlier in this region than in the others. Chl $a$ levels were highest in this zone (with an average of $0.79 \mu \mathrm{g}^{-1}$ and a maximum of $1.57 \mu \mathrm{g} \mathrm{l}^{-1}$ ). Diatom, ciliate and dinoflagellate abundances were at a maximum (70,274, 312 and 624 cells $1^{-1}$, respectively). Among the diatom community, a very low diversity $\left(H^{\prime}=0.31 \pm\right.$ 0.17) was observed of principally small diatoms (Fragilariopsis spp. dominated the community, Chaetoceros spp. were also relatively abundant). In a recent classification (Sambrotto et al. 2003) this zone was also distinguished from the rest of the region based on bathymetry, distribution of pack-ice and fast-ice, and chlorophyll levels. Studies by Samyshev in 1991 (Waters et al. 2000) have suggested that the smaller ice-seeded diatoms Fragilariopsis spp. and Chaetoceros spp. are typical of spring/early summer, when the sea-ice begins to melt and the waters are stratified. Other authors have also mentioned the importance of stratified waters for diatoms, noting that diatoms showed a positive correlation with water column stability, as stratification increases the time a cell spends in an environment with high available light for photosynthesis (Gibson et al. 1997; Goffart et al. 2000; Moro et al. 2000). In their studies diatom blooms appeared to be much more abundant in stratified waters and were frequently dominated by small pennate diatoms such as Fragilariopsis spp. or Nitzschia spp. Cores taken from the sediment near the Mertz Glacier showed abundant frustules from Fragilariopsis species, making this group the dominant diatom in recent times (Maddison et al. 2006).

Stations in the other two zones were less stratified possibly due to the mixing by the summertime katabatic winds, which are more frequent and intense in Terre Adélie and Commonwealth Bay than near the Mertz Glacier (Sambrotto et al. 2003; Vaillancourt et al. 2003). They showed similar abundances and diversity, but were separated into two groups based on the importance of certain diatom taxa.

The Astrolabe Glacier zone (Zone 1 in Fig. 10) comprised 15 stations with less nutrient-depleted waters than elsewhere in the region. This zone was characterised by average to high Chl $a$ concentrations $\left(0.68 \pm 0.14 \mu \mathrm{g} 1^{-1}\right.$ at $5 \mathrm{~m})$, high diatom diversity $\left(H^{\prime}=0.85 \pm 0.08\right)$ and average abundances $\left(3,317 \pm 2,790\right.$ cells $1^{-1}$ at $\left.5 \mathrm{~m}\right)$, and dominance of predominantly larger species such as Corethron pennatum and Rhizosolenia spp. These species are typically associated with open ocean conditions (Armand et al. 2005; Crosta et al. 2005; Maddison et al. 2006) and would thrive better in these mixed waters than the smaller pennate diatoms due to drag-inducing adaptations that reduce their sinking rate, such as long appendages (in the case of $C$. pennatum) or their needle-like morphology (for Rhizosolenia spp.). This zone is also where the highest abundances of silicoflagellates were found (maximum 460 cells $1^{-1}$ ), being very rare in the other two zones.

The Adélie Bank zone (Zone 2 in Fig. 10) was comprised of stations that were located over the shallower and warmer shelf waters. These had intermediate nutrient concentrations, yet much lower Chl a concentrations $\left(0.29 \pm 0.05 \mu \mathrm{g} \mathrm{l} \mathrm{l}^{-1}\right.$ at $\left.5 \mathrm{~m}\right)$ than the surrounding zones, and average diatom abundances $\left(3,360 \pm 1,271\right.$ cells $1^{-1}$ at $5 \mathrm{~m})$ with a low diversity $\left(H^{\prime}=0.3 \pm 0.19\right)$. These stations were characterized by the presence and high abundance of Chaetoceros spp., in particular C. criophilus. The differences between the surface water densities and nutrient concentrations of this zone and those of the Astrolabe Glacier zone being so low suggest that some other factor could help explain the differences in diatom abundances between the two zones. Studies done during the same campaign found the waters over the plateau to hold the largest abundances of potential grazers in the region. These include various copepods (calanoid and cyclopoid) (Swadling et al. 2008), appendicularians, euphausiids (Vallet et al., pers. communication) and fish larvae (particularly Pleuragramma antarcticum, Koubbi et al. 2008a, b), which have been known to prey on microplankton (Smetacek et al. in Marchant and Murphy 1994). The low biomass observed here may therefore very well be due to the larger grazing pressure in this zone.

Finally, the distribution of the microzooplankton component shows a preference for the waters around the Mertz Glacier and Adélie Depression where the highest average abundances of both dinoflagellates $\left(354 \pm 180\right.$ cells $^{-1}$ ) and ciliates $\left(156 \pm 82\right.$ cells $\left.1^{-1}\right)$ were observed. This distribution coincides with the highest diatom abundances characterised by small Fragilariopsis spp. (usually not much bigger than $30 \times 5 \mu \mathrm{m}$ ). Although Chl $a$ levels are also very high to the north and west of the Astrolabe Glacier, the area is dominated by larger and chain-forming diatoms such as Corethron pennatum, Rhizosolenia sp. or Chaetoceros spp., and grazing studies have shown a net preference by microherbivores for the smaller primary producers (preferably below the $20 \mu \mathrm{m}$ fraction) and an avoidance of the larger, chain-forming diatoms (Froneman and Perissinotto 1996).

\section{Conclusions}

The microplankton communities in the coastal waters between Terre Adélie and the Mertz Glacier were dominated by diatoms. Both the cartographic representations and the 
correspondence analysis of the species composition allowed the region to be separated into three zones each represented by a dominant group: the Mertz Glacier-Adélie Depression zone with stratified waters characterised by low diversity due to very high abundances (chl a $0.79 \pm 0.37$; diatoms $22,919 \pm 18,249$ cells $^{-1}$ at $5 \mathrm{~m}$ ) and dominated by the small colonial Fragilariopsis spp.; the Astrolabe Glacier zone where diversity was high, abundances average (chl $a$

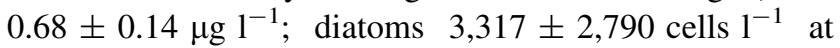
$5 \mathrm{~m}$ ) and the diatom community was principally composed of larger species such as Corethron pennatum and Rhizosolenia spp; and the Adélie Bank zone over the shallower shelf waters where biomasses were lower (chl $a 0.29 \pm$ $0.05 \mu \mathrm{g} \mathrm{l}^{-1}$; diatoms $3,360 \pm 1,271$ cells $^{-1}$ at $5 \mathrm{~m}$ ), coinciding with a large presence of herbivorous zooplankton, and where the small chain-forming Chaetoceros criophilus and similar species were dominant.

Acknowledgments We thank Captain Yvon Guédez, the crew of the RV l'Astrolabe, Alain Pottier and Patrice Godon for logistics onboard and adaptation of the Astrolabe for allowing scientific work. Funding was provided by IPEV (France), Zone Atelier Antarctique (France, INSU-CNRS) and BELSPO (Belgium) under contract EV/ 12/30A. We also thank Patrice Pruvost and Camille White for help with the field work and Lucie Courcot for helping with the S.E.M. Jean-Henri is Senior Research Associate to the FNRS (Fonds National de la Recherche Scientifique, Belgium). This work is the MARE publication no. 120 (University of Liège, Belgium).

\section{References}

Armand LK, Crosta X, Romero O, Pichon J-J (2005) The biogeography of major diatom taxa in Southern Ocean sediments: 1. Sea ice related species. Palaeogeogr Palaeoclimatol Palaeoecol 223:93-126

Arrigo KR, van Dijken GL (2003) Phytoplankton dynamics within 37 Antarctic coastal polynya systems. J Geophys Res 108:3271

Bindoff NL, Rosenberg MA, Warner MJ (2000) On the circulation and water masses over the Antarctic continental slope and rise between 80 and $150^{\circ}$ E. Deep Sea Res Part II Top Stud Oceanogr 47:2299-2326

Chiba S, Hirawake T, Ushio S, Horimoto N, Satoh R, Nakajima Y, Ishimaru T, Yamaguchi Y (2000) An overview of the biological/ oceanographic survey by the RTV Umitaka-Maru III off Adelie Land, Antarctica in January-February 1996. Deep Sea Res Part II Top Stud Oceanogr 47:2589-2613

Crosta X, Romero O, Armand LK, Pichon J-J (2005) The biogeography of major diatom taxa in Southern Ocean sediments: 2. Open ocean related species. Palaeogeogr, Palaeoclimatol, Palaeoecol 223:66-92

Delille D, Fiala M, Rosiers C (1995) Seasonal changes in phytoplankton and bacterioplankton distribution at the ice-water interface in the Antarctic neritic area. Mar Ecol Prog Ser 123:225-233

El-Sayed SZ (2005) History and evolution of primary productivity studies of the Southern Ocean. Polar Biol 28:423-438

Fonda Umani S, Monti M, Bergamasco A, Cabrini M, De Vittor C, Burba N, Del Negro P (2005) Plankton community structure and dynamics versus physical structure from Terra Nova Bay to Ross Ice Shelf (Antarctica). J Mar Syst 55:31-46
Froneman PW, Perissinotto R (1996) Microzooplankton grazing and protozooplankton community structure in the South Atlantic and in the Atlantic sector of the Southern Ocean. Deep Sea Res I 43(5):703-721

Froneman PW, Pakhomov EA, Laubscher RK (1997) Microphytoplankton assemblages in the waters surrounding South Georgia, Antarctica during austral summer 1994. Polar Biol 17:515-522

Garibotti IA, Vernet M, Ferrario ME (2005) Annually recurrent phytoplanktonic assemblages during summer in the seasonal ice zone west of the Antarctic Peninsula (Southern Ocean). Deep Sea Res Part I Oceanogr Res Pap 52:1823-1841

Gibson JAE, Swadling KM, Burton HR (1997) Interannual variation in dominant Phytoplankton species and biomass near Davis Station, East Antarctica. NIPR Symp Polar Biol 10:77-89

Goffart A, Catalano G, Hecq J-H (2000) Factors controlling the distribution of diatoms and Phaeocystis in the Ross Sea. J Mar Syst 27:161-175

Gomi Y, Umeda H, Fukuchi M, Taniguchi A (2005) Diatom assemblages in the surface waters of the Indian Sector of the Antarctic Surface Water in summer 1999/2000. Polar Biosci 18:1-15

Gordon LI, Jennings JC, Ross AA Jr, Krest JM (1993) A suggested protocol for continuous flow automated analysis of seawater nutrients (phosphate, nitrate, nitrite and silicic acid) WOCE Hydrographic Program and the Joint Global Ocean Fluxes Study. WOCE Hydrographic Progam Office

Harris PT, Brancolini G, Bindoff N, Santis LD (2003) Recent investigations of the Mertz Polynya and George Vth Land continental margin, East Antarctica. Deep Sea Res Part II Top Stud Oceanogr 50:1335-1336

Jacques G, Fukuchi M (1994) Phytoplankton in the Indian Antarctic Ocean. In: El-Sayed SZ (ed) Southern Ocean ecology: the BIOMASS perspective. Campridge University Press, Cambridge, pp 63-78

Knox GA (1994) The biology of the Southern Ocean. Cambridge University Press, Cambridge

Kopczynska EE, Weber LH, El-Sayed SZ (1986) Phytoplankton species composition and abundance in the Indian sector of the Antarctic Ocean. Polar Biol 6:161-169

Koubbi P, Duhamel G, Hecq JH, Beans C, Pruvost P, Tavernier E, Vacchi M, Vallet C (2008a) Ichthyoplankton in the neritic and coastal zone of Antarctica and Subantarctic islands: a review. J Mar Syst (in press)

Koubbi P, Razouls S, Grioche A, Hilde D, Vacchi M, Hureau JC (2008b) Condition and diet of Pleuragramma antarcticum larvae (Nototheniidae) from Terre Adélie (Antarctica) during the summer 1996. Cybium (in press)

Maddison EJ, Pike J, Leventer A, Dunbar R, Brachfeld S, Domack EW, Manley P, McClennen C (2006) Post-glacial seasonal diatom record of the Mertz Glacier Polynya, East Antarctica. Mar Micropaleontol 60:66-88

Marchant HJ, Murphy EJ (1994) Interactions at the base of the Antarctic food web. In: El-Sayed SZ (ed) Southern Ocean ecology: the BIOMASS perspective. Campridge University Press, Cambridge, pp 267-285

Moro I, Paccagnella R, Barbante C, Andreoli C (2000) Microalgal Communities of the Sea Ice, Ice-Covered and Ice-Free Waters of Wood Bay (Ross Sea, Antarctica) During the Austral Summer 1993-94. Mar Ecol 21:233-245

Nicol S, Pauly T, Bindoff NL, Strutton PG (2000) "BROKE" a biological/oceanographic survey off the coast of East Antarctica $\left(80-150^{\circ} \mathrm{E}\right)$ carried out in January-March 1996 . Deep Sea Res Part II Top Stud Oceanogr 47:2281-2297

Priddle J, Brandini F, Lipski M, Thorley MR (1994) Pattern and variability of phytoplankton biomass in the Antarctic Peninsula region: an assessment of the BIOMASS cruises. In: El-Sayed SZ 
(ed) Southern Ocean ecology: the BIOMASS perspective. Campridge University Press, Cambridge, pp 49-61

Reay DS, Priddle J, Nedwell DB, Whitehouse MJ, Ellis-Evans JC, Deubert C, Conelly DP (2001) Regulation by low temperature of phytoplankton growth and nutruent uptake in the Southern Ocean. MEPS 219:51-64

Riaux-Gobin C, Poulin M, Prodon R, Tréguer P (2003) Land-fast ice microalgal and phytoplanktonic communities (Adélie Land, Antarctica) in relation to environmental factors during ice breakup. Antarctic Sci 15:353-364

Riaux-Gobin C, Treguer P, Dieckmann G, Maria E, Vetion G, Poulin M (2005) Land-fast ice off Adelie Land (Antarctica): short-term variations in nutrients and chlorophyll just before ice break-up. J Mar Syst 55:235-248

Riaux-Gobin C, Tréguer P, Poulin M, Vétion G (2000) Nutrients, algal biomass and communities in land-fast ice and seawater off Adélie Land (Antarctica). Antarctic Sci 12:160-171

Rivoirard J, Simmonds J, Foote KG, Fernades PG, Bez N (2000) Geostatistics for estimating fish abundance. Blackwell, Oxford

Sambrotto RN, Matsuda A, Vaillancourt R, Brown M, Langdon C, Jacobs SS, Measures C (2003) Summer plankton production and nutrient consumption patterns in the Mertz Glacier Region of East AntarcticaDeep Sea Res Part II Top Stud Oceanogr 50:1393-1414

Scott FJ, Marchant HJ (2005) Antarctic marine protists. ABRS \& AAD, Canberra
Swadling KM, Koubbi P, Hecq JH, Wright SW, Sultan E, Goffart A (2008) Zooplankton-environment relationships along the East Antarctic coast $\left(139^{\circ} \mathrm{E}-145^{\circ} \mathrm{E}\right)$ in summer. Deep Sea Research I (submitted)

Tréguer P, Le Corre P (1975) Manuel d'analyse des sels nutritifs dans l'eau de mer. Laboratoire d'Océanographie Chimique, Université de Brest Occidentale, Brest

Vaillancourt RD, Sambrotto RN, Green S, Matsuda A (2003) Phytoplankton biomass and photosynthetic competency in the summertime Mertz Glacier Region of East Antarctica. Deep Sea Res Part II Top Stud Oceanogr 50:1415-1440

Waters RL, van den Enden R, Marchant HJ (2000) Summer microbial ecology off East Antarctica $\left(80-150^{\circ} \mathrm{E}\right)$ : protistan community structure and bacterial abundance. Deep Sea Res Part II Top Stud Oceanogr 47:2401-2435

Wright SW, van den Enden RL (2000) Phytoplankton community structure and stocks in the East Antarctic marginal ice zone (BROKE survey, Jan-Mar 1996) determined by CHEMTAX analysis of HPLC pigment signature. Deep Sea Res Part II Top Stud Oceanogr 47:2363-2400

Zapata M, Rodriguez F, Garrido JL (2000) Separation of chlorophylls and carotenoids from marine phytoplankton: a new method using reversed-phase C8 column and pyridine-containing mobile phases. Mar Ecol Prog Ser 195:29-45 